\title{
Agroresource potential of reclaimed lands of humid zone of Ukraine
}

\section{Tarariko Yu.}

Institute of water problems and melioration of NAAS, Vasylkivska, 37, Kyiv, 03022, Ukraine; e-mail: urtar@bigmir.net

The purpose. To assess current state of use of reclaimed lands of humid zone of Ukraine and to work out directions increasing efficiency of their use on the basis of quantity indicators of productivity of separate cultures and efficiency of crop rotations at improvement of conditions of humidifying, nutritious mode of soil, optimization of factor of crop rotation. Methods. Field tests, system generalization, analysis and synthesis, comparison, imitating computer modelling. Results. Tendencies of changes of hydrothermal conditions in region in view of their influence on structure of areas under crops and productivity of field cultures are covered. Concerning existing and expected climatic changes the necessity is proved to increase watering of territories by optimization of conditions of humidifying during droughty periods of vegetation. Potential of bioefficiency of basic soil types on natural background of fertility under condition of optimization of nutritious, water-air mode and factor of crop rotation is determined. Assessment of productivity of cultures and efficiency of crop rotations is carried out at different branch structures of reclaimed agro-eco-systems of Polissia. Regular application of scientifically-proved systems of fertilizing increases humus stocks in soddy podzolic soil up to $30 \mathrm{t} /$ hectare, as well as its security with mobile forms of nitrogen, phosphorus and potassium from low and average up to high and very high. Additional optimization of crop rotation and water-air factors in Left-bank Polissia promotes increase of productivity of cultivated soddy podzolic soils from 4,5 t/hectare on natural background of fertility up to 19,0 t/hectare; in Right-bank Polissia on clay soddy podzolic soils - from 2 up to 10 t/hectare; in Western Polissia on organogenic soils - from 4 up to 14 t/hectare. Economic efficiency of different variants of use of drained lands is brought. Prime actions on maintenance of effective use of reclaimed lands of humid zones are specified. Conclusions. The potential of bioefficiency of drained lands of Polissia can reach 20 t/hectare. Formation of adapted to available agroresource potential of branch structure of agrarian manufacture will enable to receive the net profit at the level of 200 thousand $\mathrm{hrn} /$ hectare. For maintenance of efficient use of reclaimed lands of humid zone it is necessary to adopt system of prime measures, in particular, to develop and accept Strategy of efficient use of drained lands.

Key words: land reclamation, drained agro-ecosystems, changes of climate, productivity of cultures, efficiency of crop rotations, branch structure, economic efficiency, prime measures.

\section{https://doi.org/10.31073/agrovisnyk201809-02}

Reclamation of the land of the humid zone of Ukraine is an important factor in the sustainable and efficient agricultural production, a prerequisite for the development of animal husbandry, the raw material base for industry, as well as bioenergy production. The effectiveness of the use of drained lands depends to a large extent on the economic, eco-logical and social stability of the Polissya regions [1].

The total area of dehydrated agricultural land is 3.3 million hectares, of which the required water-air regime of soils is provided on an area of about 1.8 million hectares, and over 500 thousand hectares is not used due to unsatisfactory hydrogeological-reclamation condition lands, technical condition of the drainage network and organizational and economic factors [2].

All this combined with significant changes in the climate, fragmentation of the structure of crops and crop rotation, low level of resource supply, narrow crop specialization led to deterioration of the use of reclaimed land and requires the restoration and improvement of reclamation systems on the basis of guaranteed optimal wetting conditions, appropriate adaptation of crop growing technologies and, in general, intergovernmental optimization of agrarian production [3]. 
The purpose of research. To estimate agroresource potential of drained lands of the humid zone, to establish perspective directions of its rational use. Solving these problems allows us to make scientifically based strategic and operative management decisions based on specific quantitative indices of the yield of crops and the productivity of crop rotation for improving the humidity conditions, the nutrient regime of the soil, optimizing the crop rotation factor and, in general, the formation of a balanced industry structure of agrarian production [4,5]. It is on this scientific basis that a high level of efficiency of the use of reclaimed land in the humid zone is achieved, as one of the priority areas for the agrarian sector of the Ukrainian economy [6].

Methods of research. To assess the changes in conditions of cultivation and yield of agricultural crops, data from the State Statistics Committee and the Hydrometeorological Center of Ukraine, which were processed by the methods of system-wide generalization, analysis and synthesis, by equation, were used. Studies on increasing the efficiency of the use of drained lands were performed on the information base of the network of stationary agrotechnical experiments of scientific institutions of the NAAS [7] as part of the Scientific and Methodological Center "Water Resources and Reclamation", in particular the Institute of Water Problems and Land Reclamation of the National Academy of Sciences of Ukraine, Institute of Agriculture of the Polissya of NAAS, Institute of Agriculture of the Western region of NAAS, Institute of Agricultural Microbiology and Agro-Industrial Production of NAAS. The search for promising directions for the development of dehydrated agroecosomes was carried out by multivariate, imitative computer simulation using the software complex "Agro-ecosystem" [8, 9].

Research results. It was established that due to the increase of the thermal regime, the area of excess moisture and humid zones decreased by $10 \%$ and now occupies 7.6 million hectares of arable land of Ukraine; the area of Polissya is marked by an increase in the yield of grain and leguminous crops by $44 \%$ (from $2.98 \mathrm{t} / \mathrm{ha}$ in 1990 to $4.3 \mathrm{t} / \mathrm{ha}$ in 2011-2015), while in the Forest-Steppe - by 35\%, and in the Steppe, in other case, there is a decrease of $22 \%$. As a result of the increase in the level of heat supply, there is a spread of heat-intensive crops in this area: the area of corn for grain, as compared to 1990, has increased from 82 to 695 thousand hectares, sunflower and soybeans - from - 2 to 200 - 250 thousand hectares.

Consequently, taking into account climate change in the direction of lowering the favorable conditions of cultivation of main crops, reclaimed land should be considered an insurance fund of the state. In the period from 1961 to 2015 the average annual air temperature in the Polissya zone has increased from 6.3 to $8.6^{\circ} \mathrm{C}$, or $2.3^{\circ} \mathrm{C}$. The overall dynamics of annual rainfall is directed towards a slight increase, but in the summer, this indicator is markedly reduced. If the guide-roterminal coefficient (GRC) for April-September from 1961 to the end of the 80 's of the last century increased from 1.22 to 1.58 , then this indicator is now 1.24.

That is, the terms of humidification of the growing season have changed from moist and excessively moist to insufficiently moist. As a result, favorable hydrothermal conditions for the growth and development of main crops during their active vegetation are formed only in $50 \%$ of cases, $40 \%$ - the possible spread of arid phenomena and $10 \%$ of the consequences - excessive moisture. As a result of the deviation of hydrothermal conditions from optimal yield losses of cultivated crops, they can exceed $30-40 \%$ of the middle-aged level.

By preserving the current tendency to decrease the annual climatic-water balance (CWB) in the future, one can expect a significant deterioration of the humidity conditions in the humid zone of Ukraine. In the long run, by 2050, the CWB deficit in the region may reach 70-80 mm per year, at the end of the spring period, the CWB will stabilize at its original value, and by the end of August its deficit will reach $40-70 \mathrm{~mm}$, which would not be adequate as wet zone. Under these conditions, requires the development of new approaches and technologies for the use of agricultural land in the Polissya area, where the regulation of the water regime of the soil is mainly reduced to the dumping of surplus spring floods.

These methods should be based on the increase of water areas through the creation of a system of accumulation of water resources and the introduction of technologies for optimizing the conditions of moisture during dry periods of vegetation, in particular, the creation of irrigation systems. That is, in the conditions that are being prepared and expected, the guaranteed optimization of the water regime of the drained lands, in accordance with the requirements of agricultural crops, in the first place will be ensured by 
the reconstruction, modernization and constant operation of all elements of the engineering infrastructure of the reclamation systems.

The systematic application of scientifically grounded fertilizer systems makes it possible to increase the stock of humus in the soddy-podzolic soil up to $30 \mathrm{t} / \mathrm{ha}$, to increase its availability by moving forms of nitrogen, phosphorus and potassium from low to medium to high and very high. Additional optimization of water-air and crop rotation factors in the Left-Bank Polissya promotes increased productivity of cultivated soddy-podzolic soils on the natural fertility background from $4.5 \mathrm{t}$ f.units/ha to $19 \mathrm{t}$ f.units/ha, in the Rightbank Polissya on gleyed sod-podzolic soils - from 2 to 10, in the Western Polissya on organogenic soils from 4 to $14 \mathrm{t}$ f/units/ha.

For purely planting specialization of agrarian production with growing crops giving marketable products for direct sale, the average perennial yield of corn on the natural background of fertility in the average on zonal soils is $3.5 \mathrm{t} / \mathrm{ha}$, while optimizing the water regime -5.5 , nutritional regime $-5,5-6,0$, aqueous and nutrient regimes - 8,0 - 8,5 t/ha, winter wheat respectively - 2,0; $3.5-4.0 ; 4,0-4,5$ and $7,0 \mathrm{t} / \mathrm{ha}$, winter rye 2,0 - 2,5; 3.0 - 3.5; 3,5 - 4,0 and - 5,5 t/ha, oats - 1,5 - 2,0; 3.0; 3,0 - 3,5 and 4,5 - 5,0 t/ha, barley - 1,5 - 2,0; 2.0 - 2.5; and $4.0-4.5 \mathrm{t} / \mathrm{ha}$, potatoes $-11.0-12.0 ; 23.0 ; 30,0$ and $40,0-42,0 \mathrm{t} / \mathrm{ha}$, buckwheat $-0,5 ; 9 ; 1.0$ and $1.6 \mathrm{t} / \mathrm{ha}$, flax $-0.5 ; 0.7 ; 1.0$ and $1.6 \mathrm{t} / \mathrm{ha}$ of trusts.

For crop and livestock specialization, which involves the cultivation of crop rotations of fodder crops, the yield of corn milky-wax maturation (MWM) varies in regions and under the mentioned regimes of humidification and nutrition within the limits of 12-61 t/ha, clove - 7-79, lupine - 15-56, grass timothy - 21- 57 $\mathrm{t} /$ ha of green mass. From non-traditional fodder crops on the organogenic soils of Western Polissya, the most productive in favorable conditions of cultivation turned out to be perennial Galega oritntalis and Polygonum persicaria - respectively 80 and 130 t/ha; on mineral soils - 61 and 71 , and also Lotus corniculatus - 64 t/ha, annuals - Raphanus sativus and Echinóchloa frumentácea - 91 and 80 t/ha of green mass.

In general, it should be noted that the effectiveness of separate regulation of nutrient and water-air modes of soil in most cases is one level, and the productivity of fodder crops in close to optimal conditions of cultivation is substantially superior to cereals. However, without livestock rising, a significant increase in the biological productivity of meliorated lands due to the expansion of non-grain crop areas with the production of large quantities of unclaimed plant biomass will in most cases be economically inadequate, mainly for reasons of logistic. The exception may be the generation of energy resources from it. For example, green weight or silage can be transformed into heat- and electricity energy.

For it, in the infrastructure it is necessary to involve a biogas plant, storage for silage and organic fertilizers.

According to the yield of maize under the optimal conditions of moisture and nutrition of Western Polissya $52 \mathrm{t} /$ ha of green mass, this will allow per 1 ha annually to receive 31 thousand kWh/hectare of heat- and electricity energy. In addition, all macronutrient corn crops and microelements with undiluted (approximately $50 \%$ of dry matter) after methane fermentation, the residue will return to the soil, which will make it possible to save $400-500 \mathrm{~kg}$ of active substance/ha of mineral fertilizers.

In the same region, the productivity of the village culture - Salix energy is $84 \mathrm{t} / \mathrm{ha}$. However, the expediency of expanding its area at the expense of other crops, as well as the involvement of equipment for the production of demanded end products, in particular pellets, needs analysis in relation to the specific conditions of land use.

From the standpoint of livestock development, recent research has shown that most promising is dairy cattle breeding, in the presence of a significant forage base, in particular, the potential of production of coarse and juicy feed. Taking into account that the potential of the drainage lands of Polissya for adjusting the air-water and nutrient regimes of the soil varies from 10 to $19 \mathrm{t} f$. units/ha, and the costs of feed depending on the productivity of the dairy herd make up 4 to $6 \mathrm{t} f$. units for a cow, then the maximum density of animals can be 2 - 3 conditional heads/ha. 
For example, for grain yields of $6.2 \mathrm{t} /$ ha of grain, feed - $52 \mathrm{t} / \mathrm{ha}$ of green mass with a productivity of a cow of 10 thousand kg per year, the maximum density per head is 2 conditional heads/ha, which will allow to realize $0.4 \mathrm{t} /$ ha of live weight of cattle per year and almost $12 \mathrm{t} /$ ha of whole milk.

If you add such infrastructure to modules for the processing of livestock raw materials, and all waste is disposed of on a bioenergy plant, then at the output it is possible to get $1.6 \mathrm{t} / \mathrm{ha}$ of ready-to-eat meat and dairy products, $15-16$ thousand $\mathrm{kWh} /$ hectare of heat- and electricity energy for $100 \%$ recirculation of biogenic elements.

If on the whole area of the reclaimed agro-ecosystem grow more productive than conventional cereals, conventional feed crops ( $52 \mathrm{t} /$ ha of green corn MWR, lupine, red clover, timothy) with the purchase of grain, which is especially relevant in conditions of radioactive contamination, then their density can be brought to 5.5 conditional head /ha with production of 4.5 t/ha of livestock products and obtaining 28 thousand $\mathrm{kWh} / \mathrm{hectare}$ of bioenergy.

In the case of introduction of fodder sowing changes from non-traditional fodder crops (1 - 3 - Galega officinalis, 4-5 - Polygonum, 6 - Raphanus sativus, 7-Echinóchloa frumentácea), its productivity will be 90 t/ha of green mass, loading of animals for the conditions for the purchase of "pure" concentrated feeds will reach almost 10 conditional head/ha, the production of food and energy will amount to $8 \mathrm{t} / \mathrm{ha}$ and 50 thousand $\mathrm{kWh} /$ hectare respectively.

The intensity of the nitrogen balance (percentage of return on yield) will be $260 \%$, of phosphorus - 210 and potassium - by $120 \%$ in the formation of a positive balance of organic carbon, which will provide an expanded reproduction of soil fertility and systematic increase in productivity of crop rotation.

The economic efficiency of cultivating grain crops against the background of natural soil fertility in Polissya is low, and in some years grain production is unprofitable. Regulation of water-air and nutrient soil regimes in the cultivation of crops giving crop products, in particular potatoes and cereals, makes it possible to ensure profitability at the level of 40 thousand $\mathrm{UAH} / \mathrm{ha}$ with the payback period for the modernization of the meliorative system 5 - 7 years. Infrastructure for generating from plant biomass of electric energy, provided it is implemented at a green tariff, will provide 45 thousand $\mathrm{UAH} / \mathrm{ha}$ with a period of the cost recovery depending on the productivity of the arable land of 7-10 years. The production of pellets from wood raw materials of energy crops will allow you to receive 12 thousand $\mathrm{UAH} / \mathrm{hectare}$ of net profit with a payback of capital expenditures of 6 years. Restoration of the field of dairy cattle to 2 conditional head/ha in the reclaimed lands provides profitability at the level of 60 thousand $U A H /$ ha with a payback period of financial resources of 7 years. Addition of such an infrastructure to the biogas plant and modules for the processing of livestock products will allow to increase net profit up to 200 thousand UAH/ha with the payback period of capital expenditures 2 - 3 years. The involvement of flax crops to the sowing area structure $(20 \%)$ with the processing of raw materials slightly increases the economic efficiency of bioenergy agrarian production.

At the current stage, the main technical reasons that reduce the efficiency of the use of drained lands are: the moral and physical aging of the collector-drainage network; low water supply of reclaimed territories; lack of water sources for humidifying crops during arid periods of the year; imperfection of existing technologies of water management of drained soils; low level of exploitation of the agrarian reclamation network; reducing the throughput capacity of the open channels network due to their blocking and overgrown.

That is why the main prerequisite for the effective use of drained lands of the rubber zone in the long run is the introduction of resource-saving ecologically safe constructions of drainage-humidifying systems and technologies of water management, based on the principles:

- guaranteed double-sided adjustment of water regime of drained soils (drainage-humidifying and drainage-irrigation systems);

- increase water supply of the systems by accumulation of local surface and drainage drains, additional attraction of water sources located outside the melioration areas;

- provision of autonomous control of individual modules of systems (block-modulating principle of designing); 
- ensuring ecological balance in the reclaimed territories, in the basins of the rivers in the zones of the influence of reclamation systems and in preventing the emergence of negative consequences, in the first place, such as wind erosion;

- integrated protection of agricultural lands and settlements from flooding in flood periods.

The primary measures to ensure the effective use of reclaimed land in the humane zone are:

1. Development and adoption of a general state program (strategy) for the effective use of drainage lands.

2. At the legislative level, resolve the issue of restoration of the technological integrity of the meliorative systems of the humid zone - the return of the internal economic network from the communal to the national ownership to the balance of the State service of exploitation of the State Agency of Ukraine for Water Supply.

3. Extension of the legislative framework concerning:

- introduction of adaptive-landscape bioenergy systems on the basis of organic farming on drained lands;

- increasing the responsibility of land users for the use, preservation and reproduction of fertility of drained soils;

- improvement of the management structure

water management and reclamation complexes and creation of operational enterprises of mixed form of ownership, including associations of land-water users.

4. Strengthening the system of state control over the use of drainage lands and the establishment of water and land management structures at the local level (associations, municipal enterprises).

5. Development of order and tariffs for the provision of paid services for the regulation of the water-air regime, in particular for the removal of flood waters from the reclaimed areas.

\section{Conclusions}

Over the past decades, there have been significant changes in the conditions of cultivation, crop yields and the structure of the crop area of agricultural crops, in particular in the humid zone of Ukraine. This situation has led to an objective assessment of the potential of bioproductivity of the drained lands of Polissya, which under certain conditions can reach $20 \mathrm{t}$ conditional units/ha. Computer modeling of various variants of the development of reclaimed agroecosystems has shown, that the formation of adapted to the existing agricultural resource potential of the sectoral structure of agrarian production will allow to receive net income at the level of 200 thousand $\mathrm{UAH} / \mathrm{ha}$. In order to ensure the efficient use of reclaimed lands of humid zone, a system of urgent measures should be used, in particular, to develop and adopt a nationwide program (strategy) for efficient use of drained lands.

\section{Bibliograh}

1. Melioratsiia ta oblashtuvannia ukrainskoho Polissia. [Reclamation and improvement of Ukrainian Polissya]. Kherson: OLDI - PLluS, 2018. 854 p. [in Ukrainian].

2. Kontseptsiia efektyvnoho vykorystannia osushuvanykh zemel humidnoi zony Ukrainy (naukovi zasady). [The concept of the effective use of drained lands in humid zone of Ukraine (the scientific basis)]. Kyiv: TsP «Komprynt», 2015. 22 p. [in Ukrainian].

3. Intehrovane upravlinnia vodnymy i zemelnymy resursamy na meliorovanykh terytoriiakh: monohrafiia. [Integrated management of water and land resources in the reclaimed territories: a monograph]. Kyiv: Ahrarna nauka, 2016. 784 c. [in Ukrainian].

4. Tarariko Yu.O., Datsko L.V., Melnychuk A.O. (2015). Realizatsiia ahroresursnoho potentsialu kultur na osushuvanykh zemliakh Tsentralnoho Polissia. [Realization of agro-resource potential of crops on drained lands of Central Polessye]. Melioratsiia i vodne hospodarstvo. Vol. 102. P. 34 - 36. [in Ukrainian].

5. Bioorhanichni systemy zemlerobstva $v$ zoni osushennia (rekomendatsii). [Bioorganic systems of agriculture in the drainage zone (recommendations)]. Kyiv: DIA, 2014. 216 p. [in Ukrainian].

6. Meliorovani ahroekosystemy. [Reclaimed agroecosystems]. Kyiv, Nizhyn: Vydavets PP Lysenko M.M., 2017. 696 p. [in Ukrainian]. 
7. Dovhostrokovi statsionarni polovi doslidy Ukrainy. Reiestr atestativ. [Long-term stationary field experiments of Ukraine. Register of certificates]. Kharkiv: Drukarnia № 13, 2006. 120 p. [in Ukrainian].

8. Formirovanie ustoychivykh agroekosistem. [Formation of sustainable agroecosystems ]. Kiev: DIA, 2007. P. 300. [in Russian].

9. Rozrobka gruntozakhysnykh resurso- ta enerhozberihaiuchykh system vedennia silskohospodarskoho vyrobnytstva $z$ vykorystanniam kompiuternoho prohramnoho kompleksu: rekomendatsii. [Development of ground protecting resources and energy-saving systems for agricultural production using a computer software complex: recommendations]. Kyiv: Nora-Druk, 2002. 122 p. [in Ukrainian].

10. Romashchenko M.I. (2015). Raionuvannia terytorii Ukrainy za rivnem zabezpechenosti hidrotermichnymy resursamy $v$ umovakh hlobalnykh klimatychnykh zmin. [Dissemination of the territory of Ukraine by the level of availability of hydrothermal resources in the conditions of global climate change]. Zb. nauk. prats «Grunty ta melioratsiia: mynule i maibutnie». Kyiv. P. 11 - 16. [in Ukrainian]. 